\title{
Could biodiversity loss have increased Australia's bushfire threat
}

Gibbons, J.M.; Hayward, M.W.; Ward-Fear, G.; L'Hotellier, F.L.; Hermen, K.; Kabat, A.P.; Gibbons, J.P.

\section{Animal Conservation}

DOI:

10.1111/acv.12269

Published: 01/12/2016

Peer reviewed version

Cyswllt i'r cyhoeddiad / Link to publication

Dyfyniad o'r fersiwn a gyhoeddwyd / Citation for published version (APA):

Gibbons, J. M., Hayward, M. W., Ward-Fear, G., L'Hotellier, F. L., Hermen, K., Kabat, A. P., \& Gibbons, J. P. (2016). Could biodiversity loss have increased Australia's bushfire threat. Animal Conservation, 19(6), 490-497. https://doi.org/10.1111/acv.12269

\footnotetext{
Hawliau Cyffredinol / General rights

Copyright and moral rights for the publications made accessible in the public portal are retained by the authors and/or other copyright owners and it is a condition of accessing publications that users recognise and abide by the legal requirements associated with these rights.

- Users may download and print one copy of any publication from the public portal for the purpose of private study or research.

- You may not further distribute the material or use it for any profit-making activity or commercial gain

- You may freely distribute the URL identifying the publication in the public portal ?

Take down policy

This is the peer reviewed version of the following article 'Could biodiversity loss have increased Australia's bushfire threat?' which has been published in final form at http://onlinelibrary.wiley.com/doi/10.1111/acv.12269/full. This article may be used for non-commercial purposes in accordance with Wiley Terms and Conditions for Self-Archiving.

Take down policy

If you believe that this document breaches copyright please contact us providing details, and we will remove access to the work immediately and investigate your claim.
} 
Matt W. Hayward ${ }^{1,2,3^{*}}$, Georgia Ward-Fear ${ }^{1}$, Felicity L'Hotellier ${ }^{1}$, Kerryn Herman ${ }^{1}$,

$4 \quad$ Alexander P. Kabat ${ }^{1}$, James P. Gibbons ${ }^{2}$

${ }^{1}$ Australian Wildlife Conservancy, Subiaco East, Western Australia 6008

6

${ }^{2}$ School of Environment, Natural Resources and Geography, Bangor University, UK

7 LL572UW

8

${ }^{3}$ School of Biological Sciences, Bangor University, UK; Centre for African

9 Conservation Ecology, Nelson Mandela Metropolitan University, South Africa; and Centre for Wildlife Management, University of Pretoria, South Africa. m.hayward@bangor.ac.uk

* To whom correspondence should be addressed.

Keywords: Ecosystem services; bushfire management; cost of extinction; reintroduction;

fossorial marsupials; fire suppression; biodiversity

Word count: 5829 (including references, tables and figure captions; 3315 excluding

17 these).

\section{Abstract}

Ecosystem engineers directly or indirectly affect the availability of resources through changing the physical state of biotic and/or abiotic materials. Fossorial ecosystem engineers have been hypothesised as affecting fire behaviour through altering litter accumulation and 
breakdown, however, little evidence of this has been shown to date. Fire is one of the major ecological processes affecting biodiversity globally. Australia has seen the extinction of 29 of 315 terrestrial mammal species in the last 200 years and several of these species were ecosystem engineers whose fossorial actions may increase the rate of leaf litter breakdown. Thus, their extinction may have altered the rate of litter accumulation and therefore fire ignition potential and rate of spread. We tested whether a reduction of leaf litter was associated with sites where mammalian ecosystem engineers had been reintroduced using a pair-wise, cross fence comparison at sites spanning the Australian continent. At Scotia (New South Wales), Karakamia (Western Australia) and Yookamurra (South Australia)

Sanctuaries, leaf litter mass (-24\%) and percentage cover of leaf litter (-3\%) were significantly lower where reintroduced ecosystem engineers occurred compared to where they were absent, and fire behaviour modelling illustrated this has substantial impacts on flame height and rate of spread. This result has major implications for fire behaviour and management globally wherever ecosystem engineers are now absent as the reduced leaf litter volumes where they occur will lead to decreased flame height and rate of fire spread. This illustrates the need to restore the full suite of biodiversity globally.

\section{Introduction}

Ecosystem engineers directly or indirectly affect the availability of resources through changing the physical state of biotic or abiotic materials and, as such, they modify, maintain or create habitats either autogenically or allogenically (Jones, Lawton and Shachak, 1994). Beavers Castor spp. do this through their role in dam building, which affects geomorphology and ecology, and ultimately protects rare species (Bartel, Haddad and Wright, 2010). White rhinoceros Ceratotherium simum create grazing lawns that alter fire size and heterogeneity 
47 (Waldram, Bond and Stock, 2008). Plain's viscacha Lagostomus maximus promote fire heterogeneity by gathering vegetation for nesting sites, which ultimately alters vegetation patterns (Hierro et al., 2011). Fossorial ecosystem engineers influence bioturbation and alter water infiltration, capture organic matter and increase nutrient cycling (Eldridge et al., 2015, Fleming et al., 2014).

The services provided by ecosystem engineers is frequently specific to individual species (James et al., 2011, Machicote, Branch and Villarreal, 2004) suggesting functional redundancy is rare. Consequently, the extinction of ecosystem engineers means that the ecological function they provide is unlikely to be replaced by surviving species. The plethora of studies on the functions performed by ecosystem engineers reflect their importance within ecosystems, however to date we know of no study that has illustrated the role fossorial mammalian ecosystem engineers play in regulating fire, despite this being hypothesised previously (Jones, Lawton and Shachak, 1996). In this study, we illustrate the role that fossorial ecosystem engineers play in leaf litter breakdown and how that translates to fire behaviour.

Uncontrolled wildfires cause enormous damage. For example, the total cost of 23 major wildfires in Australia between 1967 and 1999 was greater than \$AUD2.5 billion with an additional human cost of 223 deaths and 4185 injuries (Australian Institute of Criminology, 2004). In the USA, the 1998 Florida wildfire produced economic impacts of at least US\$600 million (Butry et al. 2001) and fire suppression in the USA now exceeds \$US1 billion per annum (Calkin et al., 2005). Despite improvements in communications and technology, massive wildfires are still a common event in Australia, and with climate change, increasingly so (Marris, 2016). 
Wildfire is a major conservation and land management issue globally with 179 mammal, 262 bird, 146 reptile, 300 amphibian and 974 plant species threatened by fire and fire suppression (IUCN, 2015). Leaf litter is the major source of combustible material to allow fire to spread, especially in mallee eucalypt communities (Bradstock, 1990), and fossorial species have the potential to reduce litter fuel loads (Nugent, Leonard and Clarke, 2014). Australia has suffered the loss of 29 medium-sized, ground-dwelling mammal species (Johnson, 2006, Short and Smith, 1994, Woinarski, Burbidge and Harrison, 2012), while numerous others are now restricted to offshore islands and so are extinct on the mainland (Burbidge, Williams and Abbott, 1997, McKenzie et al., 2007, Woinarski et al., 2012). Hence, the loss of these species in Australia means there is a high likelihood of cascading impacts that extend to fire regimes.

Herbivory is well documented as affecting fire regimes by removing fuel on plants and that can fall as leaf litter (Ingram, Doran and Nader, 2013, Leonard, Kirkpatrick and Marsden-Smedley, 2010). Bioperturbating species, such as bower birds and lyrebirds, alter litter volume and distribution, and thereby reduce fire likelihood (Carvalho et al., 2011, Mikami et al., 2010, Nugent et al., 2014). Here, we aimed to determine whether the extinction of members of Australia's critical weight range mammal fauna (Burbidge and McKenzie, 1989), has led to an increased accumulation of fuel that would potentially affect the rate of fire spread. This is timely given the directives of Australian state governments and Royal Commissions (Government of Victoria, 2011) regarding the area of control burns necessary to reduce the risk of life and property threatening bushfires, despite the findings that this would only reduce bushfire risk by half (Price and Bradstock, 2011). It was originally proposed that $5 \%$ of all Crown Estate in Victoria would be burnt annually on a 20 year rotation (Recommendation 56 of the 2009 Bushfires Royal Commission (Government of Victoria, 2011)), which is well below levels that would allow 'old growth' vegetation to form 
and provide habitat for old growth dependent fauna (Clarke, 2008, Clarke et al., 2010, Kelly et al., 2011, Taylor et al., 2012) and would negatively impact biodiversity (Giljohann et al., 2015).

8

9

Conservancy's (AWC) faunal restoration sites spanning the Australian continent: Karakamia (284 ha in Western Australia's jarrah forest), Scotia (64,654 ha in far-western New South Wales) and Yookamurra (5108 ha in South Australia’s Murrayland region; Fig. 1).

Karakamia receives $883 \mathrm{~mm}$, Scotia $246 \mathrm{~mm}$ and Yookamurra $275 \mathrm{~mm}$ of rain per year (AWC unpubl. data). Scotia and Yookamurra are dominated by mallee eucalypt communities on linear dunes at Scotia and on thin soils overlaying calcrete at Yookamurra, while Karakamia supports jarrah forest. All sites have large fenced areas that exclude introduced predators (red foxes Vulpes vulpes and cats Felis catus) and competitors (European rabbits Oryctolagus cuniculus and livestock) and from where such species have been eradicated. Karakamia was fully-fenced in 1994, Scotia in 2002 and 2006 (two separate 4000 ha areas), and Yookamurra in 2007. There have been no domestic herbivores on the properties since acquisition by AWC and large grazing macropod numbers are controlled within the fenced areas.

The vegetation at Scotia is generally in better condition than surrounding national parks due to a shorter pastoral history (Westbrooke, 2012, Westbrooke, Miller and Kerr, 1998). Karakamia and Scotia are situated within a matrix of largely intact vegetation, so human-impacts on fire regimes are considered minimal (Archibald et al., 2010), in contrast to Yookamurra, which sits partially within an agricultural landscape. In semi-arid areas, rainfall 
and soil moisture are limiting and limit litter decomposition rates, and the digging pits created by fossorial species are sources of higher humidity that promote litter breakdown, water infiltration and seed germination (Travers and Eldridge, 2012a, Travers and Eldridge, 2012b).

Six previously extinct species (bilby Macrotis lagotis, boodie Bettongia penicillata, bridled nailtail wallaby Onychogalea fraenata, greater stick-nest rat Leporillus conditor, numbat Myrmecobius fasciatus and woylie B. penicillata) have been reintroduced to Scotia (Finlayson, 2010, Hayward, Herman and Mulder, 2010a, Hayward et al., 2010b), four to Karakamia (woylie, southern brown bandicoot Isoodon obesulus, tammar wallaby Macropus eugenii and western ringtail possum Pseudocheirus occidentalis) and four of these have also been reintroduced to Yookamurra (bilby, boodie, numbat and woylie). Most of these species are considered as ecosystem engineers and their turnover of soil and litter could be expected to increase the rate of leaf litter breakdown (Garkaklis, Bradley and Wooller, 2004, James and Eldridge, 2007, James, Eldridge and Hill, 2009, James et al., 2011). There is no difference in the arboreal folivore communities inside and outside the fenced areas as the fences are permeable to them, so any differences in litter volumes are unlikely to be driven by browsing effects.

Paired samples were taken from one $\mathrm{m}$ to the north of eucalypt trees growing $30 \mathrm{~m}$ inside and $30 \mathrm{~m}$ outside the fences at each of 21 locations at Scotia and 20 locations at Yookamurra and Karakamia spaced one $\mathrm{km}$ apart. These paired sites had similar vegetation, topography, fire ages and the trees selected all exceeded $0.2 \mathrm{~m}$ diameter at breast height. Areas beneath canopies are the major sites of litter accumulation in the mallee (Eldridge $e t$ al., 2012). Each sample consisted of leaf litter collected in a $22 \times 22 \mathrm{~cm}$ quadrat. This material was then sieved through one mm sieves and air dried for a month. At Scotia, we also compared the number of animal digging pits and logs inside and outside the fences by 
counting them $1 \mathrm{~m}$ either side of a $50 \mathrm{~m}$ long transect, while percentage cover of cryptogamic crust cover, bare ground cover and vegetation cover were estimated visually by two observers.

Paired differences in leaf litter between fenced and unfenced plots were analysed using a linear mixed effect model in the lme4 package (Bates et al., 2013) in R (R Core Development Team, 2008) with site as a random effect. As absolute leaf litter levels varied strongly by site, relative change in levels in the unfenced plots was analysed. Ninety-five percent $(95 \%)$ confidence intervals for the relative differences were estimated using profile likelihood. Linear regression models were used to determine whether there was a difference in ground cover inside and outside the fences at Scotia. We also ran paired $t$-tests on individual site data.

Finally, to assessed how changes in leaf litter caused by reintroduced mammals might affect fire behaviour, we used mean fuel-load inputs from Scotia with conditions based on those experienced during a wildfire in September 2012 to run the McArthur Mk5 Forest Fire Behaviour model (Noble, Gill and Bary, 1980). This model is widely used by fire services 

decrease (95\% CI 6-43\%) in leaf litter mass in the fenced plots compared to the unfenced plots across sites. Scotia had significantly more leaf litter than Yookamurra and Karakamia (Fig. 2). The mass of leaf litter found inside the fences was significantly less at Karakamia $\left(23 \pm 2 \mathrm{~g}\right.$ cf $41 \pm 2 \mathrm{~g} ;$ paired $\left.t_{19}=-6.586, p<0.001\right)$, Scotia $(155 \pm 21 \mathrm{~g}$ cf $223 \pm 35 \mathrm{~g} ;$ paired $\left.t_{20}=-2.158, p=0.043\right)$ and Yookamurra $\left(24 \pm 1 \mathrm{~g} \mathrm{cf} 55 \pm 3 \mathrm{~g}\right.$; paired $t_{19}=-2.158, p=0.046$; Fig. 2).

The linear model showed there was no significant difference in percentage ground cover inside and outside fences at Scotia, however there were significant differences in ground cover types, as well as an interaction between fencing and cover type (Table 1). There was significantly less leaf litter cover inside Scotia's fenced areas compared to outside (Wald $\chi^{2}=13.495$, d.f. $\left.=1, p<0.001\right)$, but significantly more $\operatorname{logs}\left(\right.$ Wald $\chi^{2}=37.432$, d.f. $=1, p<$ 0.001 ) and pits (Wald $\chi^{2}=29.272$, d.f. $=1, p<0.001$ ) inside fenced areas (Fig. 3). Leaf litter covers only $3 \%$ less area inside fences, but is $37 \%$ less in volume (dry weight) compared to sites outside the fences.

The McArthur fire behaviour model predicted flame heights during the September 2011 fire at Scotia to reach $1.41 \mathrm{~m}$ outside the fences compared to $0.37 \mathrm{~m}$ inside the fences. to $0.12 \mathrm{~km} \mathrm{hr}^{-1}$ inside the fences. This equates to a $74 \%$ reduction in flame height and a $33 \%$ reduction in the rate of fire spread.

\section{Discussion}

This study highlights the benefits of reintroducing ecosystem engineers for the services they offer to fire management that have been lost from the majority of Australia's 
environment. These species probably play similar roles globally given the widespread distribution of fossorial species and the ubiquitous role that turning litter plays in speeding its breakdown. Such reintroductions may reduce the need for fire suppression and control in numerous fire-prone environments, which are costly and dangerous practices. The fossorial nature of the reintroduced marsupials has increased the rate of leaf litter breakdown compared to introduced fossorial species as native species dig deeper and wider pits than introduced rabbits Oryctolagus cuniculus due to the larger amount of litter and soil they turn over (Eldridge et al., 2012, James and Eldridge, 2007, Pollock, 2006). This in turn increases the return of nutrients into the soil (Eldridge et al., 2012, Elliot, Hunt and Walker, 1988). However, the reduction in available leaf litter also reduces fire spread as leaf litter is the biggest factor driving this (Bradstock, 1990). With reduced leaf litter, the risk of fire ignition is also reduced. Ultimately, a reduction in fire frequency is likely to slow the rate of carbon released into the atmosphere compared to current rates, because of the more rapid and complete release of carbon during fire than in the slow carbon pool driven by litter breakdown (Bond-Lamberty et al., 2007).

This is a global issue given reviews show that 447 mammalian genera spanning the globe have fossorial species that may significantly disturb the soil and leaf litter (Kinlaw, 1999) and many of these are likely to be threatened or locally extinct. Some taxa obviously turn over litter to increase decomposition rates. For example, Philippine porcupines Hystrix pumila are listed as vulnerable (IUCN, 2015) and, as fossorial rodents, are likely to affect litter decomposition (Bragg, Donaldson and Ryan, 2005). The rooting of suids clearly increases the rate of decomposition (Sandom, Hughes and Macdonald, 2013) and several of these are threatened including the Palawan bearded pig Sus ahoenobarbus, bearded pig $S$. barbatus, Visayan warty pig S. cebifrons, Oliver's warty pig S. oliveri, Philippine warty pig S. philippensis and the Javan warty pig S. verrucosus (IUCN, 2015). Fire is a major 
environmental problem in the range states of many of the species discussed above (Page et al., 2002).

A wildfire at Scotia provided additional support for the hypothesised ecosystem services provided by fossorial reintroduced fauna on fire behaviour. The fire burnt out rapidly where reintroduced ecosystem engineers were present, but continued to burn for several hours where they were absent (for further details see Appendix). While the relationship between leaf litter and bushfire is complex and each of our study sites is likely to respond differently to fire, we believe this anecdote illustrates the impact of the altered leaf litter cover and volume on fire behaviour.

It is important to point out the limitations of this study. There are potential differences between the inside and outside of the fences beyond the presence of ecosystem engineers including the presence of introduced herbivores (rabbits and goats Capra hircus), potential local rainfall variation and the reintroduced species within the fences may be at artificially high densities in the absence of dingoes Canis lupus and this may enhance the fuel differences. Future studies should investigate how the change in leaf litter cover and volumes that we found affects fire behaviour in the field. Nugent et al. (2014) did this using a chronosequence approach with superb lyrebirds Menura novaehollandiae and was able to model the impact on fire behaviour. Given the intensive fire management implemented by engineers (Woinarski et al., 2012) are likely to have impacted a vast array of ecological features, including fire regimes. Altered fire regimes are a threat to numerous species of 
biodiversity, and in New South Wales alone this includes 14 endangered ecological communities, 39 threatened plant species, four birds and ten mammals (NSW Scientific Committee, 2012), highlighting that the loss of functionally unique species undermines entire ecosystems (O'Gorman et al., 2011). Yet the most fire-prone forested environments of eastern mainland Australia are bereft of numerous species of critical weight range mammals and ecosystem engineers (e.g. Tasmanian bettongs Bettongia gaimardi, eastern barred bandicoots Perameles gunni, potoroos Potorous spp., etc). Their value in reducing the impact and spread of fires may be further evidence of the need to restore them to the environment. Tasmania retains an intact herbivore fauna, but still experiences devastating fires suggesting forest type may interact with ecosystem engineers to affect leaf litter breakdown or fire behaviour, and that, even in the presence of these fossorial species, extensive wildfires will still occur in Australia (albeit at a lesser frequency).

There have been questions about the efficacy of control burning in reducing bushfire risk (Bradstock, 2003, Brewer and Rogers, 2006, Pinol, Beven and Viegas, 2005). Fuel reduction burns theoretically reduce fuel loads and make fire suppression more feasible (Cheney, 1994), however post-fire leaf fall rapidly replenishes this source of fuel (Travers and Eldridge, 2012b). Also other factors, such as ambient weather and recent rainfall, affect fire behaviour (Price and Bradstock, 2011). This is the first study that identifies the potential fire suppressive effect of native mammalian fauna via the increased breakdown of leaf litter to reduce fuel loads. This is a fascinating issue as the decline of critical weight range fauna in Australia has been linked to altered fire regimes (Carwardine et al., 2011, Fitzsimons et al., 2010, Woinarski et al., 2010), however there may be a feedback loop relationship occurring with native fauna reducing fuel loads and thereby reducing their risk of increased predation following fire (McGregor et al., 2014). 
species, it has direct relevance to wildlife restoration and fire management globally.

Throughout the world, mammals are declining and fossorial ecosystem engineers are no exception (Davidson, Detling and Brown, 2012). Thus, this study provides more evidence of the value of conserving these species and restoring them to sites where they have been extirpated, to avert the functional homogenisation of the planet (Clavel, Julliard and Devictor, 2010). Furthermore, restoring ecosystem engineers is a practice that reduces fuel loads while (Dombeck, Williams and Wood, 2004). improving this manuscript.

\section{References}

Alexander, M. E. , Cruz, M. G. (2012). Interdependencies between flame length and fireline intensity in predicting crown fire initiation and crown scorch height. Int. J. Wildl. Fire 21, 95-113.

Archibald, S., Nickless, A., Govender, N., Scholes, R. J. , Lehsten, V. (2010). Climate and the inter-annual variability of fire in southern Africa: a meta-analysis using long-term field data and satellite-derived burnt area data. Global Ecol. Biogeog. 19, 794-809. 
Australian Institute of Criminology (2004). The Cost of Bushfires. 1. Criminology, A. I. o. (Ed.). Canberra, Australia: Australian Institute of Criminology.

Bartel, R. A., Haddad, N. M., Wright, J. P. (2010). Ecosystem engineers maintain a rare species of butterfly and increase plant diversity. Oikos 119, 883-890.

Bates, D., Maechler, M., Bolker, B. , Walker, S. (2013). lme4: Linear mixed-effects models using Eigen and S4. R package version 1.

Bradstock, R. A. (1990). Relationships between fire regimes, plant species and fuels in mallee communities. In The Mallee Lands: a Conservation Perspective.: pp 218-223. Noble, J. C., Joss, P. J. , Jones, G. K. (Eds.). Melbourne, Australia: CSIRO.

Bradstock, R. A. (2003). Protection of people and property: toward an integrated risk management model. In Australia Burning: Fire Ecology, Policy and Management Issues.: pp 119-123. Cary, G. J., Lindenmayer, D. B. , Dovers, S. (Eds.). Melbourne: CSIRO Publishing.

Bragg, C. J., Donaldson, J. D. , Ryan, P. G. (2005). Density of Cape porcupines in a semiarid environment and their impact on soil turnover and related ecosystem processes. $J$. Arid Environ. 61, 261-275.

Brewer, S. , Rogers, C. (2006). Relationships between prescribed burning and wildfire occurrence and intensity in pine-hardwood forests in north Mississippi, USA. Int. J. Wildl. Fire 15, 203-211.

Burbidge, A. A. , McKenzie, N. L. (1989). Patterns in the modern decline of Western Australia's vertebrate fauna: causes and conservation implications. Biol. Conserv. 50, 143-198.

Burbidge, A. A., Williams, M. R., Abbott, I. (1997). Mammals of Australian islands: factors influencing species richness. J. Biogeog. 24, 703-715. 
Byram, G. M. (1959). Combustion of forest fuels. In Forest Fire: Control and Use.: pp 6184. Davis, K. P. (Ed.). New York, USA: McGraw-Hill.

Carvalho, K. S., Alencar, A., Balch, J. , Moutinho, P. (2011). Leafcutter ant nests inhibit lowintensity fire spread in the understory of transitional forests at the Amazon's forestsavanna boundary. Psyche Entomol. 2012, 1-7.

Carwardine, J., O'Connor, T., Legge, S., Mackey, B. G., Possingham, H. P. , Martin, T. G. (2011). Priority Threat Management to Protect Kimberley Wildlife. Brisbane, Australia: CSIRO Ecosystem Sciences.

Cheney, P. (1994). The effectiveness of fuel reduction burning for fire management. In Fire and Biodiversity: the Effects and Effectiveness of Fire Management.: pp 9-16. Sosebee, R. E., Wester, D. B., Britton, C. M., McArthur, E. D. , Kitchen, S. G. (Eds.). Canberra, Australian Capital Territory: Biodiversity Unit, Department of Environment, Sport and Territories.

Clarke, M. F. (2008). Catering for the needs of fauna in fire management: science or just wishful thinking? Wildl. Res. 35, 385-394.

Clarke, M. F., Avitabile, S. C., Brown, L., Callister, K. E., Haslem, A., Holland, G. J., Kelly, L. T., Kenny, S. A., Nimmo, D. G., Spence-Bailey, L. M., Taylor, R. S., Watson, S. J. , Bennett, A. F. (2010). Ageing mallee eucalypt vegetation after fire: insights for successional trajectories in semi-arid mallee ecosystems. Australian Journal of Botany 58, 363-372.

Clavel, J., Julliard, R. , Devictor, V. (2010). Worldwide decline of specialist species: toward a global functional homogenization? Front. Ecol. Env. 9, 222-228.

Davidson, A. D., Detling, J. K. , Brown, J. H. (2012). Ecological roles and conservation challenges of social, burrowing, herbivorous mammals in the world's grasslands. Front. Ecol. Env. 10, 477-486. 
Eldridge, D. J., Travers, S., Val, J. , Kwok, A. (2012). Ecosystem Engineering Studies at Scotia Sanctuary.: 21). Kensington, Australia: University of New South Wales, Australian Wildlife Conservancy and the Office of Environment and Heritage.

Eldridge, D. J., Woodhouse, J., Curlevski, N., Hayward, M. W., Brown, M. E. , Neilan, B. (2015). Soil foraging animals alter the composition and co-occurrence of microbial communities in a desert shrubland. ISME Journal In press.

Elliot, E. T., Hunt, H. W. , Walker, D. E. (1988). Detrital food-web interactions in north American grassland ecosystems. Agriculture, Ecosystems and Environment 24, 41-56.

Finlayson, G. R. (2010). The Reintroduction of Medium-sized Marsupials in western New South Wales. PhD, University of Sydney.

Fitzsimons, J., Legge, S., Traill, B. J. , Woinarski, J. C. Z. (2010). Into Oblivion? The Disappearing Native Mammals of Northern Australia.). Melbourne: The Nature Conservancy.

Fleming, P. A., Anderson, H., Prendergast, A. S., Bretz, M. R., Valentine, L. E., Hardy, G. E. S. (2014). Is the loss of Australian digging mammals contributing to a deterioration in ecosystem function? Mamm. Rev. 44, 94-108.

Garkaklis, M. J., Bradley, J. S. , Wooller, R. D. (2004). Digging and soil turnover by a mycophagous marsupial. J. Arid Environ. 56, 569-578.

Giljohann, K., McCarthy, M., Kelly, L. , Regan, T. (2015). Choice of biodiversity index drives optimal fire management decisions. Ecol. Appl. 25, 264-277.

Government of Victoria (2011). The 2009 Victorian Bushfires Royal Commission Final Report.). Melbourne, Victoria: Government of Victoria.

Hayward, M. W., Herman, K. , Mulder, E. (2010a). Update of Australian Wildlife Conservancy Re-introductions. Reintroduction Specialist Group e-Newsletter 1, 1112. 
Hayward, M. W., Legge, S., Parsons, B. C., Page, M. J., Herman, K., Mulder, E. (2010b). Woylie Bettongia penicillata (Potoroidae: Marsupialia) reintroduction as part of the Australian Wildlife Conservancy's Endangered Species Recovery Programme at Scotia Sanctuary, far western New South Wales, Australia. In Global Re-introduction Perspectives: 2010: Additional Case Studies from Around the Globe.: pp 202-207. Soorae, P. S. (Ed.). Abu Dhabi, UAE: IUCN Species Survival Commission's Reintroduction Specialist Group.

Hierro, J., Clark, K., Branch, L. , Villarreal, D. (2011). Native herbivore exerts contrasting effects on fire regime and vegetation structure. Oecologia 166, 1121-1129.

Ingram, R. S., Doran, M. P. , Nader, G. (2013). Planned herbivory in the management of wildfire fuels. In Herbivory: pp 61-76. Barros, B. , Fernandes, M. (Eds.). Rijeka, Croatia: InTech.

IUCN (2015). IUCN Red List of Threatened Species. Version 2014.3 www.iucnredlist.org.

James, A. I. , Eldridge, D. J. (2007). Reintroduction of fossorial native mammals and potential impacts on ecosystem processes in an Australian desert landscape. Biol. Conserv. 138, 351-359.

James, A. I., Eldridge, D. J. , Hill, B. M. (2009). Foraging animals create fertile patches in an Australian desert shrubland. Ecography 32, 723-732.

James, A. I., Eldridge, D. J., Koen, T. B. , Moseby, K. E. (2011). Can the invasive European rabbit (Oryctolagus cuniculus) assume the soil engineering role of locally-extinct natives? Biol Invasions 13, 3027-3038.

Johnson, C. N. (2006). Australia's Mammal Extinctions: a 50,000 Year History. Canberra, Australia: CSIRO Publishing.

Jones, C. G., Lawton, J. H. , Shachak, M. (1994). Organisms as ecosystem engineers. Oikos 69, 373-386. 
Jones, C. G., Lawton, J. H. , Shachak, M. (1996). Organisms as ecosystem engineers. In Ecosystem management: pp 130-147): Springer.

Kelly, L. T., Nimmo, D. G., Spence-Bailey, L. M., Haslem, A., Watson, S. J., Clarke, M. F. , Bennett, A. F. (2011). Influence of fire history on small mammal distributions: insights from a 100-year post-fire chronosequence. Div. Distrib. 17, 462-473.

Kinlaw, A. (1999). A review of burrowing by semi-fossorial vertebrates in arid environments. J. Arid Environ. 41, 127-145.

Leonard, S., Kirkpatrick, J. , Marsden-Smedley, J. (2010). Variation in the effects of vertebrate grazing on fire potential between grassland structural types. J. Appl. Ecol. 47, 876-883.

Machicote, M., Branch, L. C. , Villarreal, D. (2004). Burrowing owls and burrowing mammals: are ecosystem engineers interchangeable as facilitators? Oikos 106, 527535.

Marris, E. (2016). Tasmanian bushfires threaten iconic ancient forests. Nature 530, 137-138.

McGregor, H., Legge, S., Jones, M. E. , Johnson, C. J. (2014). Landscape management of fire and grazing regimes alters the fine-scale habitat utilisation by feral cats. PLOS ONE In press.

McKenzie, N. L., Burbidge, A. A., Baynes, A., Brereton, R. N., Dickman, C. R., Gordon, G., Gibson, L. A., Menkhorst, P., Robinson, A. C., Williams, M., Woinarski, J. C. Z. (2007). Analysis of factors implicated in the recent decline of Australia's mammal fauna. J. Biogeog. 34, 597-611.

Mikami, O. K., Katsuno, Y., Yamashita, D. M., Noske, R. , Eguchi, K. (2010). Bowers of the Great Bowerbird (Chlamydera nuchalis) remained unburned after fire: is this an adaptation to fire? J. Ethol. 28, 15-20. 
Noble, I., Gill, A. , Bary, G. (1980). McArthur's fire-danger meters expressed as equations. Aust. J. Ecol. 5, 201-203.

NSW Scientific Committee (2012). Ecological consequences of high fire frequency - key threatening process listing. http://www.environment.nsw.gov.au/threatenedspecies/EcologicalConsequencesFires KTPListing.htm.). Hurstville, Australia: Office of Environment and Heritage.

Nugent, D. T., Leonard, S. W. , Clarke, M. F. (2014). Interactions between the superb lyrebird (Menura novaehollandiae) and fire in south-eastern Australia. Wildl. Res. 41, 203-211.

O'Gorman, E. J., Yearsley, J. M., Crowe, T. P., Emmerson, M. C., Jacob, U., Petchey, O. L. (2011). Loss of functionally unique species may gradually undermine ecosystems. Proceedings of the Royal Society of London (Series B) 278, 1886-1893.

Page, S. E., Siegert, F., Rieley, J. O., Boehm, H.-D. V., Jaya, A. , Limin, S. (2002). The amount of carbon released from peat and forest fires in Indonesia during 1997. Nature 420, 61-65.

Pinol, J., Beven, K. , Viegas, D. (2005). Modelling the effect of fire-exclusion and prescribed fire on wildfire size in Mediterranean ecosystems. Ecol. Mod. 183, 397-409.

Pollock, M. (Ed.) (2006) Fruit and Vegetable Gardening in Australia., London, UK, The Royal Horticultural Society.

Price, O. F. , Bradstock, R. A. (2011). Quantifying the influence of fuel age and weather on the annual extent of unplanned fires in the Sydney region of Australia. Int. J. Wildl. Fire 20, 142-151.

R Core Development Team (2008). R: A Language and Environment for Statistical Computing. Vienna, Austria: R Foundation for Statistical Computing. 
Sandom, C. J., Hughes, J. , Macdonald, D. W. (2013). Rooting for Rewilding: quantifying wild boar's Sus scrofa rooting rate in the Scottish Highlands. Rest. Ecol. 21, 329-335.

Short, J. , Smith, A. P. (1994). Mammal decline and recovery in Australia. J. Mammal. 75, 288-297.

Taylor, R. S., Watson, S. J., Nimmo, D. G., Kelly, L. T., Bennett, A. F. , Clarke, M. F. (2012). Landscape-scale effects of fire on bird assemblages: does pyrodiversity beget biodiversity? Div. Distrib. 18, 519-529.

Travers, S. K. , Eldridge, D. J. (2012a). Above-average rainfall triggers an increase in fall rates of reproductive structures in an arid eucalypt woodland. Austral Ecol. In review.

Travers, S. K. , Eldridge, D. J. (2012b). Landscape modulators and resource accumulation in a post-fire eucalypt woodland. For. Ecol. Mmt. 285, 11-19.

Waldram, M. S., Bond, W. J. , Stock, W. D. (2008). Ecological engineering by a megagrazer: white rhino impacts on a South African savanna. Ecosystems 11, 101-112.

Westbrooke, M. E. (2012). The pastoral history, biological and cultural significance of the Scotia Country, far western New South Wales. Proceedings of the Linnaen Society of New South Wales. 134, A55-A68.

Westbrooke, M. E., Miller, J. D. , Kerr, M. K. C. (1998). The vegetation of the Scotia 1:100 000 map sheet, western New South Wales. Cunninghamia 5, 665-684.

Woinarski, J. C. Z., Armstrong, M., Brennan, K. E. C., Fisher, A., Griffiths, A. D., Hill, B. M., Milne, D. J., Palmer, C. L., Ward, S., Watson, M., Winderlich, S. , Young, S. S. (2010). Monitoring indicates rapid and severe decline of native small mammals in Kakadu National Park, northern Australia. Wildl. Res. 37, 116-126.

Woinarski, J. C. Z., Burbidge, A. A. , Harrison, P. L. (2012). The Action Plan for Australian Mammals 2012. Melbourne, Australia: CSIRO Publishing. 
459 Scotia. Wald post-hoc tests revealed no effect of fencing on the area covered by any of

460 the ground cover types at Scotia (bare earth, cryptogamic crust, leaf litter, logs, animal 461 digging pits or vegetation).

\begin{tabular}{llll}
\hline Source & Wald $\chi^{2}$ & d.f. & Probability \\
\hline Intercept & 745.975 & 1 & $<0.001$ \\
Fenced/unfenced & 0.001 & 1 & 0.974 \\
Ground cover type & 326.629 & 5 & $<0.001$ \\
Interaction & 344.594 & 11 & $<0.001$ \\
& & & \\
\hline
\end{tabular}


465 Fig. 1. Location map of the Australian Wildlife Conservancy's sanctuaries showing Karakamia, Scotia and Yookamurra.

467 Fig. 2. Mean ( \pm 2 S.E.) mass of leaf litter inside and outside fences at the Australian Wildlife Conservancy’s Karakamia, Scotia and Yookamurra Sanctuaries.

469 Fig. 3. Mean ( \pm 2 S.E.) percentage ground cover of bare earth, cryptogamic crust, leaf litter, logs, animal digging pits and vegetation inside and outside fences at the Australian Wildlife Conservancy's Scotia Sanctuary. Significant differences based on Wald's $\chi^{2}$ test are shown with asterisks $(* * *$ denoting significance at $p<0.001)$. 


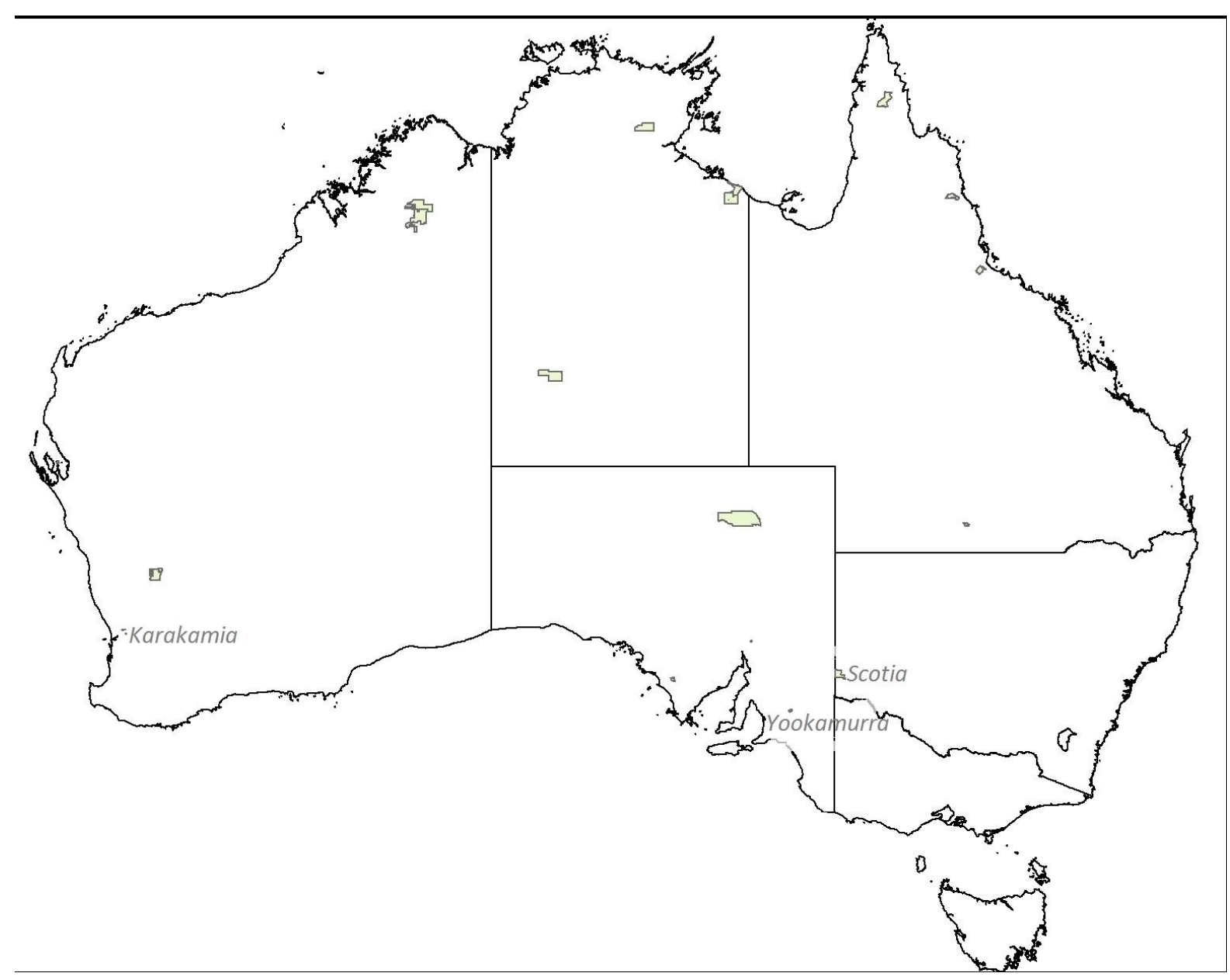

475

Fig. 1

476 


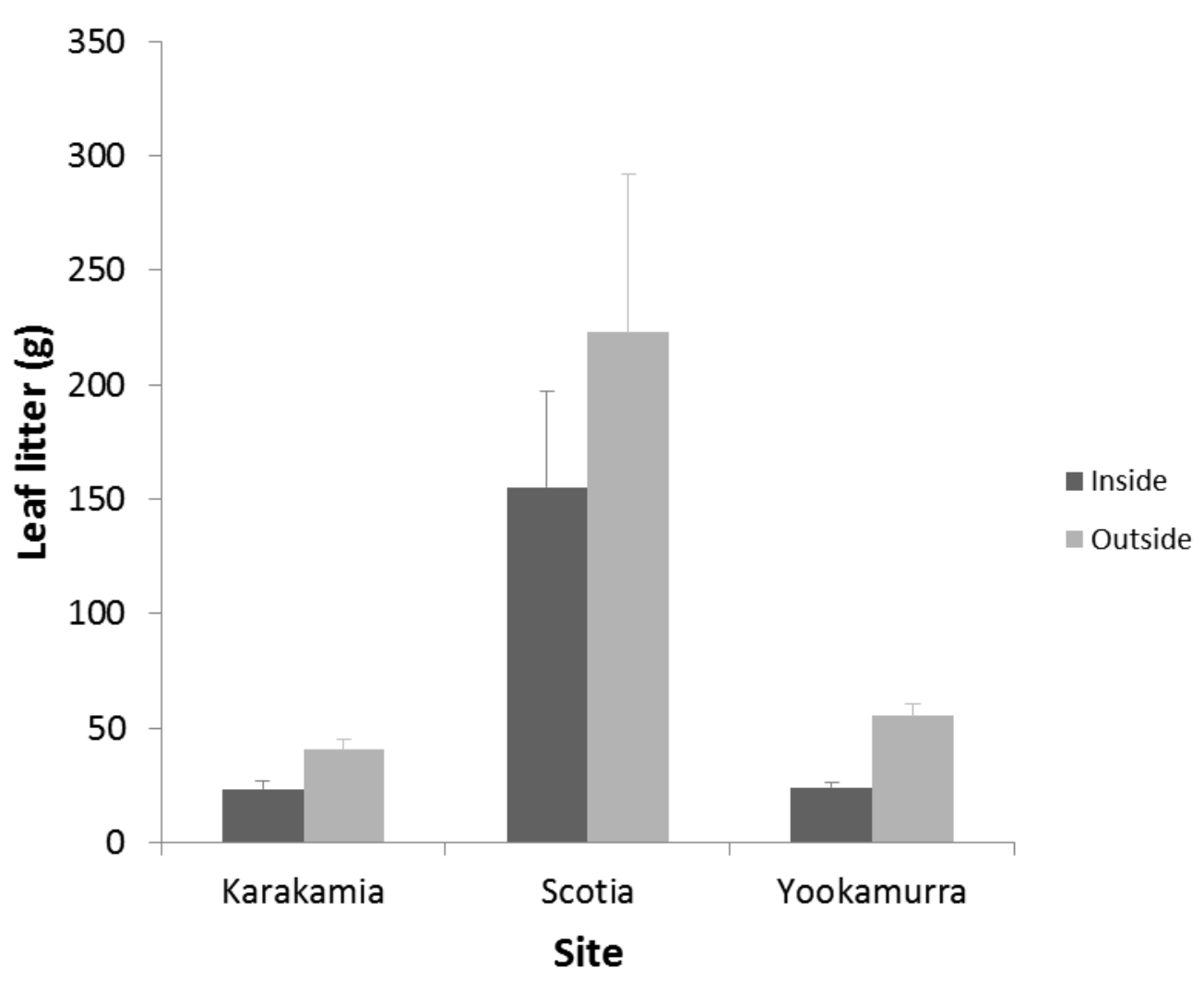

477

478

Fig. 2

479 


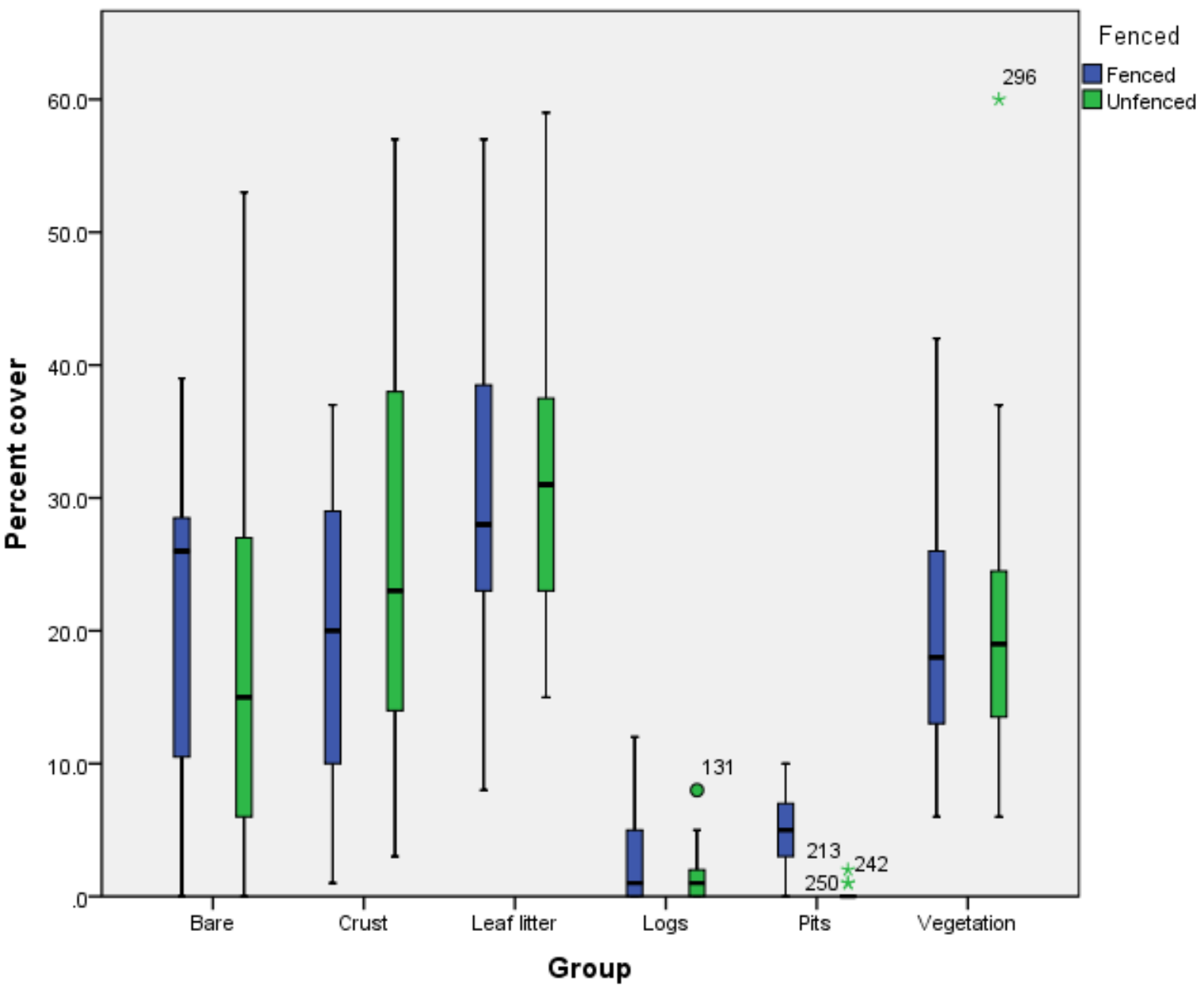

480

481

482

483

484

Fig. 3.

485

486 
A wildfire started from an overnight lightning strike in the north-western corner of Scotia in

September 2012 and burnt slowly to the south from when it was detected at 0830 am until approximately 1300 , when a strong wind change pushed it to the east (Fig. A1). The fire crossed several potential fire breaks including vehicle tracks, an 8m cleared area along the

492 fence line protecting the reintroduced fauna, and fire breaks created earlier in 2011 and in 2010, to enter the fenced area around 1730. By $1900 \mathrm{hrs}$, the fire inside the fenced area where reintroduced fauna occurred, had reached the extent shown in Fig. S1, however despite weather conditions remaining fairly constant (and temperatures exceeding $30^{\circ} \mathrm{C}$ ) it did not progress further, while the fire continued to burn out the finger to the south for the rest of the night (Fig. S1). Water was hosed on flames inside the fenced area where the fire was in reach of vehicle tracks, however it is clear that large areas of long unburnt vegetation contiguous to the fire and away from tracks did not burn (Fig. S1). Cool conditions arrived around 0500hrs and the fire risk was largely alleviated via minor mopping up operations. We hypothesise that the rapid cessation of fire in the fenced area was due to the reduced leaf litter caused by its rapid breakdown by the actions of the ecosystem engineers that have been reintroduced there. Whether this difference in fire behaviour was due to the reduced litter volumes inside the fences or the reduced connectivity due to the lower percentage cover of leaf litter (or both) is unknown. While the relationship between leaf litter and bushfire is complex and each of our study sites is likely to respond differently to fire, we believe this anecdote illustrates the impact of the altered leaf litter cover and volume on fire behaviour. 
509

510

511

512

513

514

515

516

517

Fig. A1. Fire scar from the September 2012 wildfire at Scotia. The dark red polygon is the boundary of the 2012 fire, while earlier fires are also shown (1985/6 in lime green; 1995-6 in bright green; 2010/11 controlled burn in pale green along the Stage 1/2 fenced boundary where native fossorial mammals have been reintroduced in 2002 and 2006 respectively). Uncoloured areas have not been burnt for over 40 years. The 2012 wildfire started from a lightning strike during a typical dry thunderstorm in the north-western corner of the fire scar. Topography is shown in greyscale with darker shades depicting higher elevations.

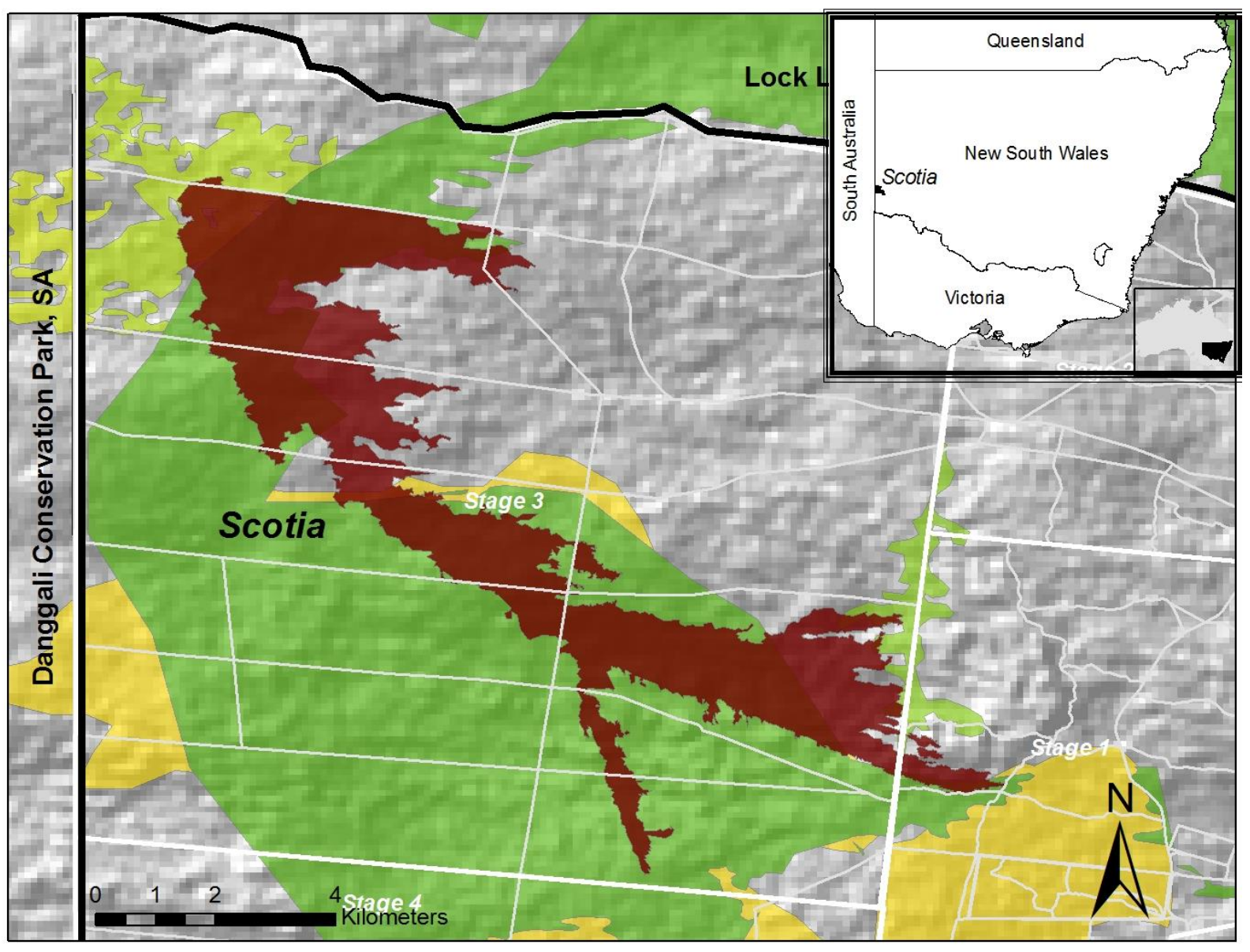

Fig. A1 